\title{
Demography of the land snail Tikoconus (Tikoconus) costaricanus (Stylommatophora: Euconulidae) in tropical low montane and premontane forests, Costa Rica
}

\author{
Zaidett Barrientos \\ Laboratorio de Ecología Urbana, Universidad Estatal a Distancia, 2050 San José, Costa Rica; zbarrientos@uned.ac.cr
}

Received 15-II-2019. Corrected 10-VII-2019. Accepted 27-IX-2019.

\begin{abstract}
Introduction: Ecology and natural history of neotropical land snails is almost unknown. Objetive: In this paper, I analyse the population dynamics of Tikoconus (Tikoconus) costaricanus Barrientos, an understory endemic euconulid. Methods: I compared T. costaricanus' demography patterns in tropical montane forests in central Costa Rica in three habitats with different restoration techniques: a mature forest, a secondary forest and a Cuppressus lusitanica plantation. I collected data in three month periods during a year. I analysed population size in relation with habitat, sampling date, leaf litter humidity, depth and quantity; and specimen size in relation with habitat and sampling date. I also kept some specimens in terraria and described part of their natural history. Results: The species is more abundant in mature forest $\left(\varnothing=0.174 \mathrm{ind} / \mathrm{m}^{2}\right)$. The number of specimens in each habitat was constant throughout the year (Kruskall-Wallis $=2.0118, p=0.57, \mathrm{NS}$ ) and hatching occurs in the middle and last months of the rainy season (Kruskall-Wallis $=17.3061, \mathrm{P}=0.00061$, **). Number of specimens is related with leaf litter humidity (Spearman correlation, $\mathrm{r}=0.3524, \mathrm{n}=232, \mathrm{P}<$ $0.001, * *$ ), quantity (Spearman correlation, $\mathrm{r}=0.3922, \mathrm{n}=232, \mathrm{P}<0.001, * *$ ) and depth (Spearman correlation, $\mathrm{r}=0.2543, \mathrm{n}=232, \mathrm{P}<0.001, * *)$. This relationship is explained by the high and stable humid environment provided by leaf litter. Some specimens migrate from foliage to leaf litter during the drier months. Eggs $(\varnothing=$ $1 \mathrm{~mm}$ ) are laid on moss or soil and the young spend the first 2 or 3 weeks of their life on moss. Egg masses are small ( $\varnothing=4$ eggs), and shells look bubbly. Egg development time (20 days) was longer than in other tropical species. Adult pigmentation appears around two months after hatch. In the only case observed, egg laying began 5 months after hatching and the specimen lived 9 months. Conclusions: Restorations techniques should consider leaf litter features in order to protect endemic neotropical humid dependent diversity.
\end{abstract}

Key words: life history, microdistribution, conservation, land molluscs.

Barrientos, Z. (2019). Demography of the land snail Tikoconus (Tikoconus) costaricanus (Stylommatophora: Euconulidae) in tropical low montane and premontane forests, Costa Rica. Revista de Biología Tropical, 67(6), 1449-1460.

The scarcity, small size and lack of identification keys have contributed to the little knowledge that we currently have of Neotropical land snails, and the few studies cover a limited part of the region, mostly Mexico, Brazil, Argentina, Costa Rica and Cuba (Correa-Sandoval, Strenth, Rodríguez Castro, \& Horta Vega, 2009; Barrientos, 2010, 2016; Nunes \& Santos, 2012; Suárez Torres \& Fernández-Velázquez,
2012; Miranda, Fontenelle \& Pecora, 2015). Five genera of euconulids have been reported from the Neotropics: Habroconus Fischer \& Crosse, Velifera Binney, Euconulus Reinhardt, Tikoconus Barrientos and Ovachlamys (Barrientos, 1998, 2000, 2019; Schileyko, 2002; Thompson, 2011). Only two species have been studied regarding their ecology and life history: the Brazilian native Habroconus semenlini 
(Moricand, 1845) and the introduced Japanese species Ovachlamys fulgens (Gude, 1900). The population density of $H$. semenlini was negatively affected by drought and temperature in a semi-deciduous seasonal forest (Silva, 2007). Similarly, in a forest with 5 to 6 dry months, $O$. fulgens population density followed, with some lag, the precipitation curve (Barrientos, 2000). The abundance of living $O$. fulgens snails and eggs increased with leaf litter abundance and depth, leaf litter and soil moisture, and early morning temperature; but decreased with temperature around noon (Barrientos, 2000). Until the present study, the native neotropical euconulids had not been studied in low montane and premontane forests.

As explained by Barrientos (2012) there are three major trends on forest restoration techniques applied in Costa Rica and little is known about their impact on native fauna. In this paper, I analyse the demography of $T$. (T.) costaricanus Barrientos, an endemic terrestrial snail, in three habitats with different restoration techniques in tropical low montane and premontane regions. I also present basic information on its biology.

\section{MATERIALS AND METHODS}

Research area: The study took place in the Reserva Forestal Río Macho, Orosi Valley, Costa Rica. This reserve limits with Tapantí -Macizo Cerro de la Muerte-National Park. The Reserva Forestal Río Macho has mean temperatures between 14 and $26{ }^{\circ} \mathrm{C}$ and a mean annual precipitation of $2416 \mathrm{~mm}$. The dry season lasts from December through April with precipitations between 78 and $190 \mathrm{~mm}$ per month; while the rainy season lasts from May through November with precipitations between 269 and $376 \mathrm{~mm}$ (Instituto Metereológico Nacional, station El Llano dam, years 2009-2010, only complete monthly data were considered).

I selected three habitats (Fig. 1): a mature forest; a restored forest with natural ecological succession, known as unassisted restoration or secondary forest; and a Cupressus lusitanica plantation, a commercially important introduced species, its understory with unassisted restoration. The mature forest is located near El Llano dam $\left(9^{\circ} 45^{\prime} 56^{\prime \prime} \mathrm{N} \& 83^{\circ} 51^{\prime} 47^{\prime \prime} \mathrm{W}\right.$, 1640 masl), in a tropical lower montane wet forest area. The restored forest $\left(9^{\circ} 45^{\prime} 29^{\prime \prime} \mathrm{N}\right.$

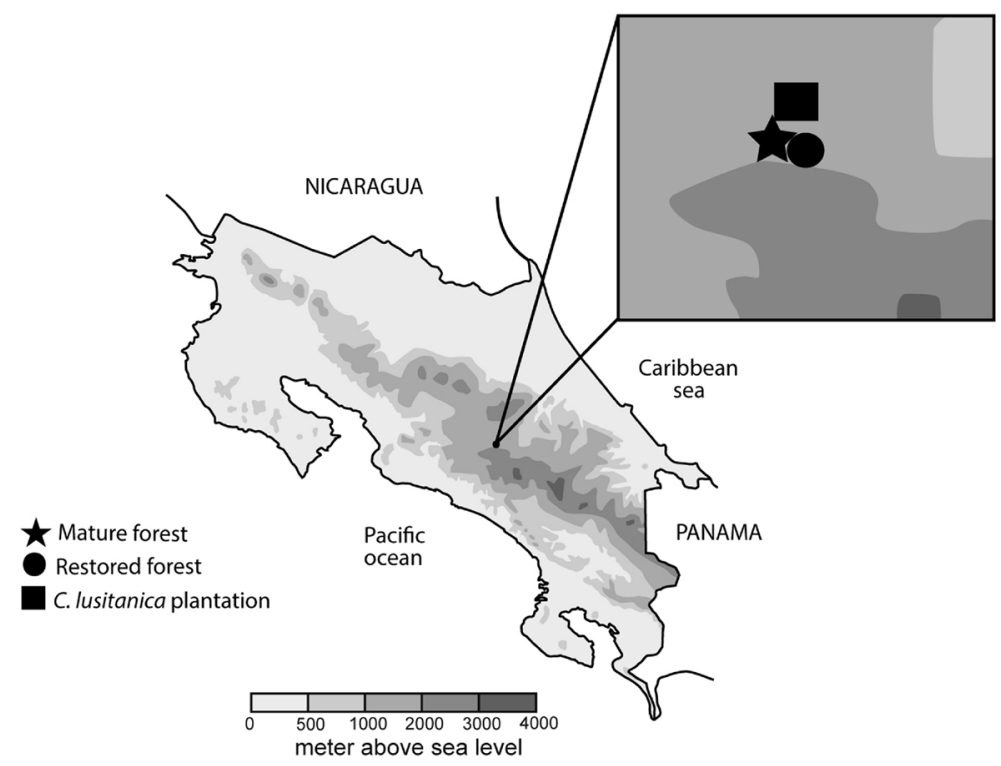

Fig. 1. Sampling sites in the Reserva Forestal Río Macho, Costa Rica. 
\& 8351'23" W, 1684 masl) has been under natural succession for about 15 years, and the understory is composed mainly of native species; the place borders a mature forest and is inside a tropical lower montane wet forest area. The Cupressus lusitanica plantation (09 ${ }^{\circ} 7^{\prime} 52$ $\mathrm{N} \& 83^{\circ} 51^{\prime} 51 \mathrm{~W}, 1309$ masl) is within a tropical humid premontane forest. This plantation has been abandoned for nearly 40 years and an understory dominated by hardwood species has developed, but is still sparse. The three places have slopes of over $40^{\circ}$.

Sampling: I collected terrestrial molluscs every three months from April 2009 to April 2010. Due to logistic problems the $C$. lusitanica plantation was sampled in April 2010 instead of April 2009. I did a total of four sampling trips in each habitat; two during the dry season (January 2010, April 2009 and April 2010) and two during the rainy season (July and October 2009).

In each sampling occasion, I set a $200 \mathrm{~m}$ line at least $10 \mathrm{~m}$ away from any trail to avoid any border effect (Pérez, 1994). With a random number generator, I chose 20 sampling plots along each line. Most ecological land snail studies use one square meter plots (Correa-Sandoval et. al., 2009; Suárez Torres, Hernández, \& Fernández, 2012; Cuasapaz-Sarabia \& Salas, 2019). However, depending on field characteristics, other plot sizes give better results (Schilthuizen, 2011; Miranda et al., 2015). In this case, I used a larger plot $\left(3 \times 3 \mathrm{~m}^{2}\right)$ to compensate for low specimen abundance and shrub differences among habitats. I set the plots with aluminum rods and plastic ropes. In each plot, I used several collecting methods (details below) for a more reliable representation of the snails at the site, because each method has its own bias (Durkan, Yeung, Meyer, Hyes, \& Cowie, 2013).

In each plot, I collected arboreal snails with a $50 \times 50 \mathrm{~cm}$ entomological beat sheet (http:// mississippientomologicalmuseum.org.msstate. edu//collecting.preparation.methods/Beating. sheet.htm) for about $7 \mathrm{~min}$ (Barrientos, 2003a). I slightly beat branches, shrubs and seedlings between 0 and $200 \mathrm{~cm}$ above ground; tree trunks were slightly scrubbed with a gardening glove. I also combined this method with visual survey: if I saw a snail, I placed it in a collecting jar and continued with the beating-sheet method. In the laboratory, I examined the litter, first with a magnifying glass (10X) and after that, with a stereoscopic microscope. I counted only specimens collected alive, because empty shells can mislead abundance surveys (Barrientos, 2000). I measured shell diameters with a Zeiss microesteroscopic scale $0.15 \mathrm{~mm}$ at $16.25 \mathrm{X}$.

In each plot, I randomly selected a $50 \mathrm{x}$ $50 \mathrm{~cm}$ subplot for additional measurements: leaf litter depth, quantity and humidity, and snail number. I measured leaf litter depth with a standard millimetric ruler in five independent places of each subplot and used the average as depth (Barrientos, 2000). I assessed leaf litter quantity by the number of hardwood tree leaves that could be threaded with an ice pick, again using the average from five samples (Barrientos, 2012). In each subplot, I collected litter, including small branches less than $5 \mathrm{~mm}$ in diameter, fragmented litter, humus and topsoil. The size of the litter sample was $439 \mathrm{~g}$ in average $(\mathrm{SD}=188, \min =89$, $\max =1470)$. I kept litter samples in a plant oven for several days until constant dry weight was reached to apply the formula: Humidity percentage $=($ wet weight - dry weight $) /$ wet weight $* 100$. I searched for specimens before and after drying the leaf litter sample first with magnifier glasses (10X) and after that with a stereoscopic microscope.

Natural history: I followed the methodology explained by Barrientos (1998). I collected T. (T.) costaricanus specimens in the mature forest and kept them in terraria with soil, leaves (mainly from Piperaceae and Melastomataceae), moss, small orchids and other plants that naturally grow on shrubs and tree stems. I kept other specimens in terraria just with fresh leaves collected in the field. I changed the leaves periodically. I kept all terraria at room temperature and checked them daily. I took 
away the eggs as soon as found and placed them in a new terrarium. I took note of number of eggs, size, development time, newborn shell diameter, growth rate, places where eggs were laid and parts of the terraria where snails where seen more often.

Analysis: I studied the snail quantity in relation with habitat, microhabitat, sampling date and leaf litter humidity, depth and quantity. I also analyzed specimen size in relation with habitat and sampling date. I detailed leaf litter humidity, quantity and depth dynamics in a previous paper (Barrientos, 2012).

The following symbols or abbreviations are used: $\varnothing=$ mean, $\mathrm{n}=$ size sample, $\mathrm{p}=$ probability, $\mathrm{SD}=$ standard deviation, $\mathrm{NS}=$ non-significant, $*=$ statistically significant, $* *$ $=$ strongly statistically significant, $\min =$ minimum, $\max =$ maximum.

Voucher specimens: I deposited voucher specimens in the Zoology Museum of the University of Costa Rica. Catalogue number MZUCR-242-01 (9 specimens). Costa Rica, Cartago, Orosi, Reserva Forestal Río Macho, at "El llano" water dam. 1640 masl. 945'56" N \& 83 $51^{\circ} 47^{\prime \prime}$ W. collected on 5 March 2012 by Zaidett Barrientos, Maribel Zúñiga \& Andrea Induni (T.: ZB-251).

\section{RESULTS}

Demography in vegetation: I found $T$. (T.) costaricanus in mature and secondary forest and in the C. lusitanica plantation. In all sampling seasons, specimens were far more abundant in mature forest (April 2009 and April 2010; Kruskall-Wallis $=17.77, \mathrm{P}=0.0001$, **), (July 2009; Kruskall-Wallis $=13.71, \mathrm{P}=$ $0.0011, * *)$, (October 2009; Kruskall-Wallis $=$ $7.85, \mathrm{P}=0.0197, *)$, (January 2010; KruskallWallis, $\mathrm{df}=22.9092, \mathrm{P}=0.00001, * *)$. Mean density was higher in mature forest, followed by secondary forest and $C$. lusitanica plantations (Table 1).

In each habitat the number of specimens throughout the year was the same independently of the season (Kruskall-Wallis $=2.0118$, $\mathrm{P}=0.57, \mathrm{NS}$ ) but the size distribution shows a higher quantity of small specimens during October (Kruskall-Wallis $=17.3061, \mathrm{P}=$ $0.00061, * *)$ (Fig. 2). Specimen size was similar in all habitats (Kruskall-Wallis $=4.08, \mathrm{P}=$ 0.13, NS) (Fig. 3).

There were more specimens where litter was moister (Spearman correlation, $r=0.3524$, $\mathrm{n}=232, \mathrm{P}<0.001, * *)$, more abundant (Spearman correlation, $\mathrm{r}=0.3922, \mathrm{n}=232, \mathrm{P}<0.001$, **) and deeper (Spearman correlation, $\mathrm{r}=$ $0.2543, \mathrm{n}=232, \mathrm{P}<0.001, * *)$.

Demography in leaf litter: I did not find $T$. (T.) costaricanus in the litter of the $C$. lusitanica plantation. I found specimens in the mature forest litter only during the dry season, especially in April (Mann-Whitney (Wilcoxon), $\mathrm{W}=152, \mathrm{P}=0.004, * *)$. In April, the mature forest's litter had a snail density of 0.35 ind $/ \mathrm{m}^{2}\left(\mathrm{~min}=0 \mathrm{ind} / \mathrm{m}^{2}, \max =8 \mathrm{ind} / \mathrm{m}^{2}, \mathrm{SD}\right.$ $=0.5871, \mathrm{n}=20)$ and the correlation between litter humidity and specimen quantity was positively significant (Spearman correlation, $\mathrm{r}=$ $\left.0.4951, \mathrm{n}=20, \mathrm{P}=0.0309,{ }^{*}\right)$. I found only two specimens in January in the mature forest and

TABLE 1

Yearly average density for Tikoconus (Tikoconus) costarricanus occurring in three habitats in Orosi Valley, Costa Rica

\begin{tabular}{ccc} 
Mature forest & Restored forest & C. lusitanica plantation \\
$\varnothing=0.174 \mathrm{ind} / \mathrm{m}^{2}$ & $\emptyset=0.047 \mathrm{ind} / \mathrm{m}^{2}$ & $\emptyset=0.018 \mathrm{ind} / \mathrm{m}^{2}$ \\
$\mathrm{n}=78$ & $\mathrm{n}=75$ & $\mathrm{n}=80$ \\
$\mathrm{SD}=1.748$ & $\mathrm{SD}=0.661$ & $\mathrm{SD}=0.489$ \\
$\min =0 \mathrm{ind} / \mathrm{m}^{2}$ & $\min =0 \mathrm{ind} / \mathrm{m}^{2}$ & $\min =0 \mathrm{ind} / \mathrm{m}^{2}$ \\
$\max =0.89 \mathrm{ind} / \mathrm{m}^{2}$ & $\max =0.33 \mathrm{ind} / \mathrm{m}^{2}$ & $\max =0.33 \mathrm{ind} / \mathrm{m}^{2}$ \\
\hline
\end{tabular}

$\varnothing=$ mean density, $\mathrm{n}=$ sample size, $\mathrm{SD}=$ Standard deviation, $\min =$ minimum, $\max =$ maximum $)$. 


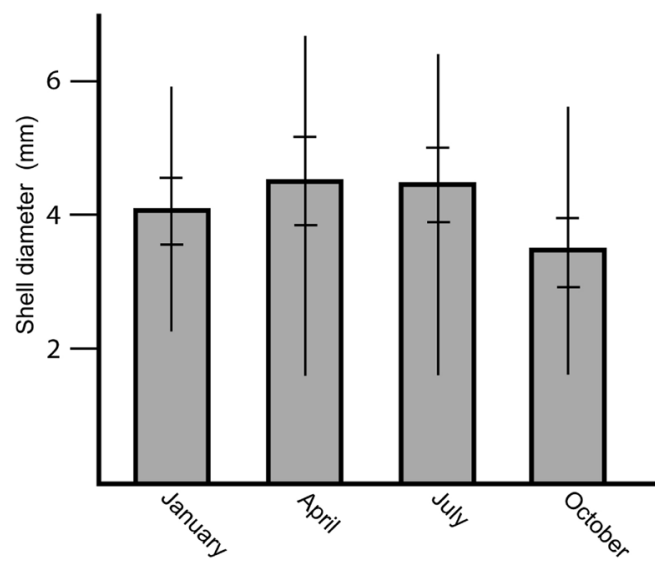

Fig. 2. Shell diameter of the snail T. (T.) costaricanus under natural conditions according to month. Vertical lines represent maximum and minimum values. Horizontal lines represent standard deviation.

one specimen in April in the secondary forest, therefore no statistical analysis was conducted.

Life history: This species lays egg masses with an average of 3.78 eggs per mass $(\min =1$,

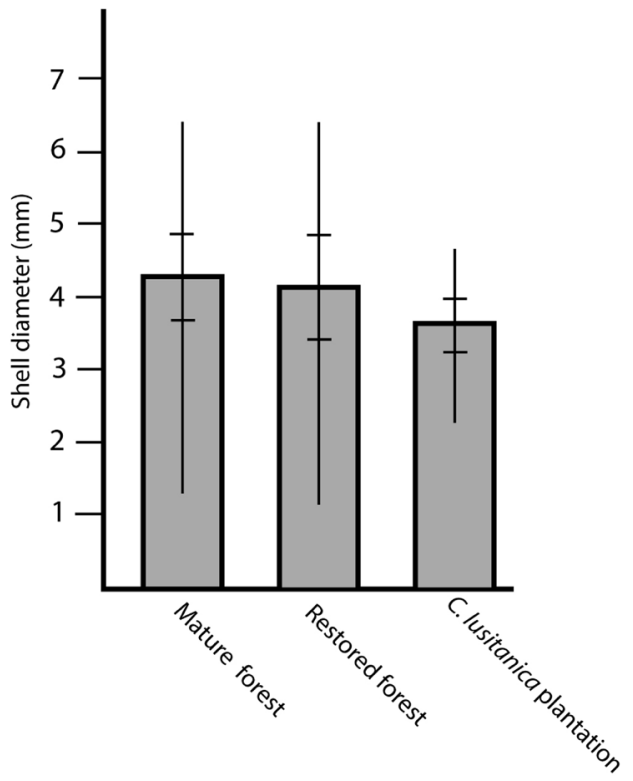

Fig. 3. Shell diameter of $T$. (T.) costaricanus in mature forest, secondary forest and a $C$. lusitanica plantation. Vertical lines represent maximum and minimum values. Horizontal lines represent standard deviation.

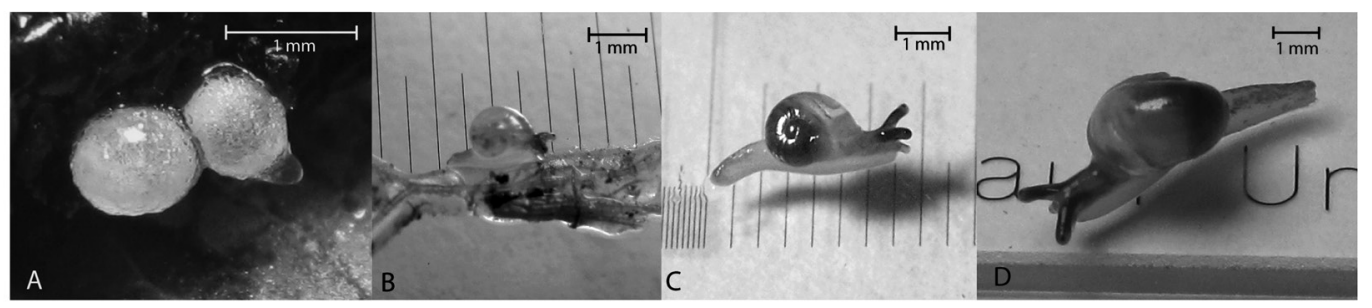

Fig. 4. Egg and pigmentation patterns of T. (T.) costaricanus according to age. A) Egg. B) Two days old specimen. C) 36 days old specimen. D) 64 days old specimen.

$\max =10, \mathrm{SD}=2.73, \mathrm{n}=9$ egg masses) in moss and in soil. When moss or soil was not added to the terrarium no eggs were laid $(n=20)$. During oviposition snails withdraw tentacles (all four) with the head stretched between very wet soil clots $(n=3)$, one specimen laid eggs on a leaf. Eggs are round and well hydrous. Egg diameter was $1 \mathrm{~mm}(\mathrm{~min}=1, \max =1, \mathrm{n}=$ 5), egg shell is translucent and looks like made of bubbles (Fig. 4A). Egg eclosion took 20 days $(n=11)$ and shell diameter two days after eclosion was $1 \mathrm{~mm}(\min =1, \max =1, \mathrm{n}=5)$.
Recently hatched specimens were transparent with a poorly defined pigmentation pattern, the species typical pigmentation appeared only after they were 64 days old (Fig. 4B, Fig 4D). Eight days after hatching specimens' shells were about $1 \mathrm{~mm}$ wide (diameter) and moved among moss and leaves but spent most time on moss. They only spent most time on leaves after 21 days from hatching, when their shell diameter was $1.27 \mathrm{~mm}$ (Fig. 5). They appear to grow during their whole life (Fig. 5). Only one terrarium-born specimen survived to the 


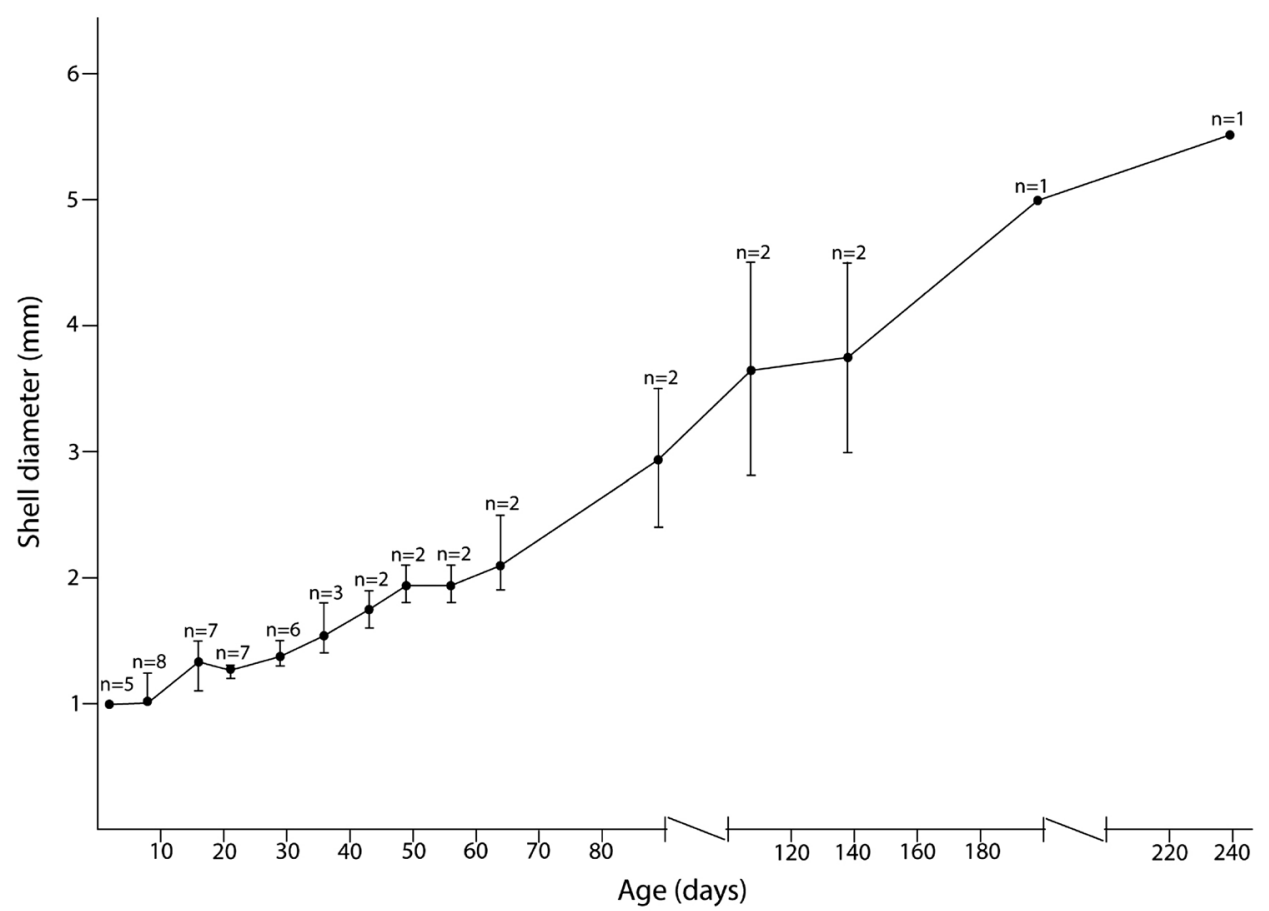

Fig. 5. Growth curve of $T$. (T.) costaricanus. Vertical lines represent maximum and minimum values. $\mathrm{N}=$ sample size.

adult stage; it began laying eggs 5 months after hatching and died when it was 9 months old.

\section{DISCUSSION}

The land snail T. (T.) costaricanus occurs in the three kinds of habitat analysed in this study. Nevertheless, it was considerably more abundant in mature forest suggesting that density depends greatly on some habitat features. This is in agreement with findings from leaf litter land snail studies, in which the number of specimens is favoured by: denser canopy and understory, higher litter humidity, thicker litter composed of many layers, higher diversity of canopy and understory composition, older and bigger trees and presence of rotten logs (Boag, 1985; Barrientos, 2000; Müller, Strätz, \& Hothorn, 2005). However, why abundance of species that spend most of their time on above ground vegetation is so related to soil litter characteristics? Probably because litter helps keeping environmental moisture.
Humidity is of key importance in tropical ecosystems (Barrientos, 2012) and T. (T.) costaricanus is adapted to forests and microhabitats with high humidity levels. Although the three habitats of this study have similar precipitations patterns, the comparison between habitats show different humidity levels (Barrientos, 2012) and the snail density varies according to their moisture.

Tropical dry habitats tend to have smaller land snail populations during the dry season (Barrientos, 2000). On the contrary, in this study, in a wetter forest the population size has no change around the year within a given habitat. However, in October, when the area has the highest litter humidity and rainfall level (Barrientos, 2012), the mean size of shells was smaller. One possible explanation is that the snail quantity was underestimated due to the presence of juveniles that hide among moss growing on trunks and stems. It is also reasonable to think that the hatching season takes place in the middle of the rainy season. A 
sympatric native species, Drymaeus tripictus, also synchronized hatchling with rainy season (Barrientos, 2016).

There are few studies on native neotropical snail density. The density of $T$. (T.) costaricanus in mature forest is similar to that of wild Liguus fasciatus in Cuba (FernándezVelázquez \& Berovides-Alvarez, 2000). Nevertheless, their shell size differs considerably as L. fasciatus is around 10 times bigger than $T$. (T.) costaricanus. However, its density is low when compared with agriculturally important species like Succinea costaricana $\left(28 \mathrm{ind} / \mathrm{m}^{2}\right)$, Subulina octona $\left(1063 \mathrm{ind} / \mathrm{m}^{2}\right)$ and $O$. fulgens (13ind $/ \mathrm{m}^{2}$ ) (Villalobos, Monge-Nájera, Barrientos, \& Franco, 1995; Monge-Nájera, 1997; Barrientos, 2000). Soil acidity, natural $\mathrm{CO}_{3}$ concentration and artificial field liming could be contributing with this difference because of their effect on shell development (Gärdenfors, 1992; Müller et al., 2005). With some notable exceptions like Cuba and Jamaica (Rosenberg \& Muratov, 2006), neotropical wildland soils are acid and poor in limestone, therefore snail abundance is low, while species diversity could be high (Emberton, 1995; Emberton, Pearce, \& Randalana, 1996; Winter \& Gittenberger, 1998; Barrientos, 2003b, 2010).

As $T$. (T.) costaricanus can be found on leaves eating algae that grow on them the year around (Barrientos, 2019), it can be considered an understory dweller. Nevertheless, the understory litter also plays an important role, not only keeping environmental moisture as explained before, but also in its life history. At the end of the dry season specimens may migrate vertically between vegetation and leaf litter, at least during the sunny hours, while in the rest of the year their presence in the litter is only casual probably because litter is too wet and compacted (Barrientos, 2012). Seasonal and daily vertical migration is not unusual in other invertebrates, however it is poorly studied in land snails (Barrientos, 2000; Naranjo-García，2003; Doblas, 2007; Cutz-Pool, Castaño-Meneses, Palacios-Vargas, \& Cano-Santana, 2010).
Litter provides protection against drought and creates structurally complex microhabitats where molluscs and other invertebrates can hide from predators and unsuitable weather (Fournier \& Herrera de Fournier, 1978; Barrientos, 2000, 2012; Sabo, Soykan, \& Keller, 2005; Palacios-Vargas et al., 2007; Bonilla, Roncall, Jimeno, \& García, 2008; Sabu, Vineesh, \& Vinod, 2008; Sampaio, RodríguezGonzález, Varandas, Cortes, \& Ferreira, 2008). However, if the litter is too dry and structurally simple, as it is in a cypress plantation (Barrientos, 2012), snails may avoid being there.

As shown in the laboratory, T. (T.) costaricanus is probably laying eggs on soil and moss and spending the first 2 or 3 weeks of their life on moss that grows on stems. This behaviour is also reported in zonitids (Heller, 2001) and helps avoiding the problems caused by the compaction effect of heavy rain in litter during rainy season (Barrientos, 2012). Small moisture-dependent species that live in a tropical cloud forest, where soil and litter can get easily saturated, find ecological and evolutionary advantages in this behavior. Moss probably provides more stable moisture and temperature than decaying leaves, as excess water can drain more easily in the moss than in the leaf litter. In this way, recently hatched specimens (shell diameter less than $1.3 \mathrm{~mm}$ ) avoid dehydration and problems caused by the cohesion force of water. Migrations between exposed and unexposed habitats have been also reported for Theba pisana (Johnson, 1981). However, more studies are need to establish if small horizontal migration is constant along their life or related only with seasons or even only with oviposition and hatching.

The places choose by $T$. (T.) costaricanus to lay eggs, its shell structure and its hydration level indicates that this is a species that evolve in a very humid environment with constant and high moisture. Other euconulids have more complex or derivate physiology to adapt them self to humidity. For example, O. fulgens can lay eggs which are not fully hydrated (Barrientos, 1998), this can be an adaptation to save corporal liquids while taking advantage 
of the presence of wet litter. Further research is needed to fully understand the evolutionary meaning of this difference.

Small specimens were underestimated with the method applied in this study. Future studies should collect all the moss that grows on stems and, due to the specimen's small size and lack of colour, sort them in the laboratory. It is important to learn more about the microhabitat that stem mosses provide for invertebrates and their role in forest moisture in tropical habitats, as has been done for temperate ecosystems (Cutz-Pool et al., 2010; García-Gómez, Castaño-Meneses, \& PalaciosVargas, 2011). For example, it has been shown that moss moisture is important for some acari (Hoffmann \& Riberón, 1992). However, I do not know of any paper dealing with the impact of moss moisture changes and the survival of recently hatched or small arboreal neotropical snails. I would expect an important relation, because treefall gaps can affect snail density, probably due to their effect on water loss rates (Alvarez \& Willing, 1993).

Incubation time of $T$. (T.) costaricanus is a little long compared to other neotropical species: Polymita muscarum (10 days) (Bidart, Fernández, \& Iglesias, 1998), Polymita venusta (8 days) (Bidart et al., 1998), O. fulgens (14 days) (Barrientos, 1998) and Succinea costaricana (11 days) (Villalobos et al., 1995). This can be a specific species characteristic or a result of different environmental temperatures (Montresor, Teixeira, Paglia, \& Vidiga, 2012): T. (T.) costaricanus' habitat is colder than the habitats of the other species for which there are reports.

The pigmentation of $T$. (T.) costaricanus varies considerably with age, and the reason may be camouflage. The small snails lack of pigmentation fits the moss where they start their life. Later, their pigmentation matches the epiphytes (lichen, moss and algae) where they live as adults. Another species, Succinea costarricana, also lacks pigmentation during the first seven weeks; the explanation for this is also camouflage and microhabitat changes during their life span (Villalobos et al., 1995). On the contrary, $O$. fulgens hatchlings and adults have the same pigmentation pattern throughout their life (Barrientos unpublished data). The explanation may also be camouflage: $O$. fulgens hatch on the soil and leaf litter, where they spend the rest of their life. Therefore, having the same colour pattern their entire life helps camouflage.

Although the sample size is small, data collected point out to a relatively short life cycle of around 9 months. Similar results were obtained for other euconulids like $O$. fulgens (Barrientos, 1998) and Habroconus semenlini, which lives only 4 months (Silva, Meireles, Vargas, Junqueira, \& Bessa, 2009). Nevertheless, both $O$. fulgens and $H$. semenlini started laying eggs much sooner, around 40 days after hatching (Barrientos, 1998, Silva et al., 2009). A late reproduction and the production of few eggs that need a long time for development, is worrisome from the point of view of conservation. More research is needed to fully understand its ecology and the population risk with habitat and climate change.

Although T. (T.) costaricanus is more common on mature forest, colonization of restored habitats is possible. Restoration techniques can chiefly affect environmental and biological features (Morrison \& Lindell, 2011; Barrientos, 2012). However, unlike the general pattern found by Morrison \& Lindell (2011) for birds, restoration strategies do affect molluscan communities. Cypress plantations are drier, have litter with less layers and shallower leaf litter than mature forest (Barrientos, 2012). Therefore, these plantations are unsuitable for animals like molluscs that depend deeply on environmental moisture (Müller et al., 2005). These restoration techniques should be reconsidered and improved in order to achieve the environmental conditions and dynamics needed by these snails and by other native species. Improvements should include plants that produce more litter and shade.

The unassisted restoration (ecological succession) represents a better restoration technique for the conservation of native snail fauna. The litter dynamic is similar to the dynamic 
of a mature forest and even though its environmental characteristics are more variable, it can also reach its humidity levels (Barrientos, 2012), therefore being more friendly to moisture dependent organisms. This restoration technique could be improved with some fast growing native trees that provide a denser canopy. Future comparison with other native species and, biology and behaviour analysis with bigger samples should show if $T$. (T.) costaricanus is significantly susceptible to climate and land use change.

Ethical statement: the author declares that she agrees with this publication; that there is no conflict of interest of any kind; and that she followed all pertinent ethical and legal procedures and requirements. All financial sources are fully and clearly stated in the acknowledgements section. A signed document has been filed in the journal archives.

\section{ACKNOWLEDGMENTS}

Andrés Monge, Danyi Prieto and Fabian Araya gave field assistance. I am especially grateful to Esteban Acuña, Gabriela Pérez and Maribel Zúñiga for field and technical assistance. Julián Monge-Nájera, Fred Thompson, Edna Naranjo and Edmund Gittenberger commented on an earlier draft. This paper was partially financied by the project "FEES-Conare Análisis ecosistémico para la evaluación de la restauración forestal y sus implicaciones en el secuestro de carbono en un bosque nublado" and by the UNED's Research Vicepresidency. Special acknowledgement to Katya Calderón and Lizette Brenes for their administrative support. This paper is part of the Ph.D. requirements, Doctorado en Ciencias Naturales para el Desarrollo at the Instituto Tecnológico de Costa Rica (ITCR), Universidad Nacional (UNA) and Universidad Estatal a Distancia (UNED).

\section{RESUMEN}

Demografía del caracol terrestre Tikoconus (Tikoconus) costaricanus (Stylommatophora: Euconulidae) en un bosque tropical montano bajo y en un bosque premontano. Introducción: La ecología y la historia natural de los moluscos terrestres neotropicales es casi desconocida. Objetivo: En este artículo analicé la dinámica poblacional de Tikoconus (Tikoconus) costaricanus Barrientos, una especie endémica que habita el sotobosque del centro de Costa Rica. Métodos: Comparé los patrones demográficos de la especie en un bosque tropical montano en tres hábitats con diferentes estrategias de restauración: un bosque maduro, un bosque secundario y una plantación de Cuppressus lucitanica. Recolecté datos en periodos de tres meses durante un año. Analicé el tamaño de la población en relación a: hábitat, fecha de muestreo, humedad, profundidad y cantidad de la hojarasca. También analicé el tamaño de los especímenes en relación al hábitat y fecha de muestreo. Mantuve algunos especímenes en terrarios y describí parte de su historia natural. Resultados: La especie fue más abundante en el bosque maduro $(\varnothing=0.174$ ind $/ \mathrm{m}^{2}$ ). La cantidad de especímenes en cada hábitat fue constante a lo largo del año (Kruskall-Wallis=2.0118, P = $0.57, \mathrm{NS}$ ) y la eclosión se presenta en la mitad y últimos meses de la estación lluviosa (Kruskall-Wallis $=17.3061$, $\mathrm{P}=0.00061, * *)$. La cantidad de especímenes estuvo relacionada con la humedad del ambiente que provee la hojarasca. Durante los meses más secos algunos especímenes migran del follaje a la hojarasca. Los huevos $(\varnothing=1 \mathrm{~mm})$ son depositados en el musgo y en el suelo y los jóvenes pasan las primeras 2 o 3 semanas de su vida en el musgo. Las masas de huevos son pequeñas $(\varnothing=4$ huevos $)$ y los huevos se ven como construidos de burbujas. El tiempo de desarrollo de los huevos (20 días) fue más prolongado que en otras especies tropicales. La pigmentación del adulto aparece alrededor de dos meses después de la eclosión. En el único caso observado la ovoposición empezó a los 5 meses después de la eclosión y el espécimen vivió hasta los 9 meses. Conclusiones: Las técnicas de restauración deben considerar las características de la hojarasca con el fin de proteger la biodiversidad neotropical endémica dependiente de la humedad del ambiente.

Palabras clave: historia natural, microdistribución, conservación, moluscos terrestres.

\section{REFERENCES}

Alvarez, J., \& Willing, M. R. (1993). Effects of Treefall Gaps on the Density of Land Snails in the Luquillo Experimental Forest of Puerto Rico. Biotropica, 25(1), 100-110. Retrieved from DOI: $10.2307 / 2388983$ 
Barrientos, Z. (2000). Population dynamics and spatial distribution of the terrestrial snail Ovachlamys fulgens (Stylommatophora: Helicarionidae) in a tropical environment. Revista Biología Tropical, 48(1), 71-87. Retrieved from http://www.scielo.sa.cr/scielo.php?script=sci arttext\&pid=S0034-77442000000100009\&lng=es\& $\bar{n}$ $\mathrm{rm}=\mathrm{iso} \&$ tlng $=\mathrm{en}$

Barrientos, Z. (2003a). Aspectos básicos sobre la clasificación, recolección, toma de datos y conservación de los moluscos. Revista Biología Tropical, 51(Supl. 3), 13-30. Retrieved from https://revistas.ucr.ac.cr/index. $\mathrm{php} / \mathrm{rbt} /$ article/view/26363/26564

Barrientos, Z. (2003b). Estado actual del conocimiento y la conservación de los moluscos continentales de Costa Rica. Revista Biología Tropical, 51(Supl. 3), 285292. Retrieved from http://www.ots.ac.cr/tropiweb/ attachments/suppls/sup51-3\%20malacol/13-Barrientos-Estado.pdf

Barrientos, Z. (2010). Los moluscos terrestres (Mollusca: Gastropoda) de Costa Rica: clasificación, distribución y conservación. Revista Biología Tropical, 58(4), 1165-1175. Retrieved from http:// www.ots.ac.cr/tropiweb/attachments/volumes/ vol58-4/09_Barrientos_Moluscos_CR.pdf

Barrientos, Z. (2012). Dynamics of leaf litter humidity, depth and quantity: two restoration strategies failed to mimic ground microhabitat conditions of a low montane and premontane forest in Costa Rica. Revista Biología Tropical, 60(3), 1041-1053. Retrieved from http://www.scielo.sa.cr/scielo.php?pid=S0034$77442012000300007 \&$ script=sci_arttext

Barrientos, Z. (2016). Reproductive system, mating behavior and basic ecology of an extremely rare tropical snail: Drymaeus tripictus (Stylommatophora: Bulimulidae). Revista de Biología Tropical, 64(1), 55-68. Retrieved from http://www. scielo.sa.cr/scielo.php?script $=$ sci_arttext\&pid $=$ S0034-77442016000100055

Barrientos, Z. (2019). A new genus of semislugs (Stylommatophora: Euconulidae) from Costa Rica and a review of the genus Velifera (Stylommatophora: Euconulidae). Revista de Biología Tropical, 67(6), 1313-1358.

Bidart, L., Fernández, A., \& Iglesias, C. (1998). Reproducción de Polymita muscarum y Polymita venusta (Stylommatophora: Helminthoglyptidae). Revista de Biología Tropical, 46(3), 683-689. Retrieved from http://www.scielo.sa.cr/scielo.php?pid=S0034$77441998000300023 \&$ script $=$ sci_arttext\&tlng=en

Boag, D. A. (1985). Microdistribution of three genera of small terrestrial snails (Stylommatophora: Pulmonata). Canadian Journal of Zoology, 63(5), 1089-1095. Retrieved from DOI: 10.1139/z85-163
Bonilla, R., Roncallo, B., Jimeno, J., \& García, T. (2008). Producción y descomposición de la hojarasca en bosques nativos y de Leucaena sp., en Codazzi, Cesar. Revista Corpoica-Ciencia y Tecnología Agropecuaria, 9(2), 5-11. Retrieved from http://www.redalyc. org/pdf/4499/449945025001.pdf

Correa-Sandoval, A., Strenth, N. E., Rodríguez Castro, R., \& Horta Vega, J. V. (2009). Análisis ecológico básico de los gastrópodos terrestres de la Región Oriental de San Luis Potosí, México. Acta Zoológica Mexicana, 25(1), 105-122. Retrieved from http:// www.scielo.org.mx/scielo.php?script=sci_arttext\&pi $\mathrm{d}=\mathrm{S} 0065-17372009000100010$

Cuasapaz-Sarabia, J., \& Salas, J. A. (2019). Área de vida de la especie invasora Achatina fulica (Gastropoda: Achatinidae) en un área de conservación de bosque seco ecuatoriano. Revista Peruana de Biología, 26(1), 41-48. Retrieved from https://dx.doi. org/10.15381/rpb.v26i1.14628

Cutz-Pool, L. Q., Castaño-Meneses, G., Palacios-Vargas, J. G., \& Cano-Santana, Z. (2010). Distribución vertical de colémbolos muscícolas en un bosque de Abies religiosa del Estado de México, México. Revista Mexicana de Biodiversidad, 81(2), 457-463. Retrieved from http://www.scielo.org. $\mathrm{mx} /$ scielo.php?pid=S187034532010000200018\&script=sci_arttext

Doblas, E. (2007). Ecología de los macroinvertebrados edáficos en un ecosistema árido mediterráneo (Tesis Doctoral). Universidad de Granada, Granada, España. Retrieved from http://digibug.ugr.es/bitstream/ handle/10481/1537/16713187.pdf;jsessionid=2D99 1E6AD86426960519EEEB288181CA? sequence=1

Durkan, T. H., Yeung, N. W., Meyer III, W. M, Hayes, K. A., \& Cowie, R. H. (2013). Evaluating the efficacy of land snail survey techniques in Hawaii: implications for conservation throughout the Pacific. Biodiversity and Conservation, 22, 3223-3232. Retrieved from https://link.springer.com/article/10.1007/ s10531-013-0580-7

Emberton, K. C. (1995). Sympatric convergence and environmental correlation between two land-snail species. Evolution, 49, 469-475. Retrieved from DOI: 10.1111/j.1558-5646.1995.tb02279.x

Emberton, K. C., Pearce, T. A., \& Randalana, R. (1996). Quantitatively sampling land-snail species richness in Madagascan rainforest. Malacologia, 38(1-2), 203212. Retrieved from https://www.biodiversitylibrary. org/page/13114990\#page/217/mode/1up

Fernández-Velázquez, A., \& Berovides-Alvarez, V. (2000). Cambios de densidad de Liguus fasciatus achatinus Clench 1934 (Mollusca: Orthalicidae) en el Yayal, Holguín, Cuba. Revista Biología, 14(2), 141-146.

Fournier, L. A., \& Herrera de Fournier, M. E. (1978). Cambios de la microflora del suelo en varias etapas de la sucesión en Ciudad Colón, Costa Rica. 
Revista Biología Tropical, 26(1), 103-112. Retrieved from https://revistas.ucr.ac.cr/index.php/rbt/article/ view/25807

García-Gómez, A., Castaño-Meneses, G., \& PalaciosVargas, J. G. (2011). Distribución y diversidad de colémbolos (Hexapoda: Collembola) en el gradiente altitudinal de un bosque templado en México. Revista Biología Tropical, 59(1), 315-327. Retrieved from http://www.scielo.sa.cr/scielo.php?pid=S0034$77442011000100028 \&$ script $=$ sci_arttext\&tlng=en

Gärdenfors, U. (1992). Effects of Artificial Liming on Land Snail Populations. Journal of Applied Ecology, 29(1), 50-54. Retrieved from DOI: $10.2307 / 2404346$

Heller, J. (2001). Life history strategies. In G. M. Barker (Ed.), The biology of terrestrial mollusks (pp. 88-91). Oxford, UK: CABI Publishing,Wallingford.

Hoffmann, A., \& Riberón, R. (1992). Biorrelaciones entre los musgos y su acarofauna en México. Tropical Bryology, 6, 105-110. Retrieved from https://core. ac.uk/download/pdf/14529879.pdf

Johnson, M. S. (1981). Effects of migration and habitat choice on shell banding frequencies in Theba pisana at a habitat boundary. Heredity, 47(1), 121133. Retrieved from https://www.nature.com/articles/ hdy198165.pdf

Miranda, M. S., Fontenelle, J. H., \& Pecora, I. L. (2015). Population structure of a native and an alien species of snail in an urban area of the Atlantic Rainforest. Journal of Natural History, 49(1-2), 19-35. Retrieved from https://www.researchgate.net/publication/263848164_Population_structure_of_a_native_and_an_alien_species_of_snail_in_an_urban area of the Atlantic Rainforest

Monge-Nájera, J. (1997). Moluscos: moluscos de importancia agrícola y sanitaria en el trópico: la experiencia costarricense. San José, Costa Rica: Editorial UCR.

Montresor, L., Teixeira, A., Paglia, A., \& Vidiga, T. (2012). Reproduction of Omalonyx matheroni (Gastropoda: Succineidae) under laboratory conditions. Revista Biología Tropical, 60(2), 553-566. Retrieved from http://www.scielo.sa.cr/scielo.php?pid=S003477442012000200004\&script=sci_arttext\&tlng=pt

Morrison, E. B., \& Lindell, C. A. (2011). Active or Passive Forest Restoration? Assessing Restoration Alternatives with Avian Foraging Behavior. Restoration Ecology, 19(201), 170-177. Retrieved from DOI: 10.1111/j.1526-100X.2010.00725.x

Müller, J., Strätz, C., \& Hothorn, T. (2005). Habitat factors for land snails in European beech forests with a special focus on coarse woody debris. European Journal of Forest Research, 124(3), 233-242. Retrieved from https://link.springer.com/article/10.1007/ s10342-005-0071-9
Naranjo-García, E. (2003). Malacofauna de la hojarasca. In J. Álvarez-Sánchez, \& E. Naranjo-García (Eds.), Ecología del Suelo en la Selva Tropical Húmeda de México (pp. 141-161). Xalapa, México: Instituto de Ecología, A.C., Instituto de Biología y Facultad de Ciencias, UNAM.

Nunes, G. K. M., \& Santos, S. B. (2012). Environmental factors affecting the distribution of land snails in the Atlantic Rain Forest of Ilha Grande, Angra dos Reis, RJ, Brazil. Brazilian Journal of Biology, 72(1), 79-86. Retrieved from DOI: http://dx.doi. org/10.1590/S1519-69842012000100010

Palacios-Vargas, J. G., Castaño-Meneses, G., GómezAnaya, J. A., Martínez-Yrizar, A., Mejía-Recamier, B. E., \& Martínez-Sánchez, J. (2007). Litter and soil arthropods diversity and density in a tropical dry forest ecosystem in Western Mexico. Biodiversity and Conservation, 16(13), 3703-3717. Retrieved from https://link.springer.com/article/10.1007/ s10531-006-9109-7

Pérez, M. A. (1994). Efecto de borde (bosque tropical lluvioso-cacaotal) en los caracoles terrestres (Mollusca: Gastropoda). Revista Biología Tropical, 42(3), 745-746. Retrieved from https://revistas.ucr.ac.cr/ index.php/rbt/article/view/23293/23598

Rosenberg, G., \& Muratov, I. V. (2006). Status report on the terrestrial Mollusca of Jamaica. Proceedings of the Academy of Natural Sciences of Philadelphia, 155, 117-161. Retrieved from https://www. researchgate.net/publication/232691550_Status Report_on_the_Terrestrial_Mollusca_of_Jamaica

Sabo, J. L., Soykan, C. U., \& Keller, A. (2005). Functional roles of leaf litter detritus in terrestrial food webs. In P. C. Ruiters, V. Wolters, \& J. C. Moore (Eds.), Dynamic food webs: Multispecies assemblages, ecosystem development, and environmental change (pp. 211-223). Burlington, Massachusetts, USA: Academic Press.

Sabu, T. K., Vineesh, P. J., \& Vinod, K. V. (2008). Diversity of forest litter-inhabiting ants along elevations in the Wayanad region of the Western Ghats. Journal of Insect Science, 8(1), 1-14. Retrieved from https://academic.oup.com/jinsectscience/article/8/1/69/903670

Sampaio, A., Rodríguez-González, P., Varandas, S., Cortes, R. M., \& Ferreira, M. T. (2008). Leaf litter decomposition in western Iberian forested wetlands: lentic versus lotic response. Limnetica, 27(1), 93-106. Retrieved from https://www.repository.utl.pt/ handle/10400.5/5138

Schileyko, A. A. (2002). Treatise on recent terrestrial pulmonate mollusks: Punctidae, Helicodiscidae, Discidae, Cystopeltidae, Euconulidae, Trochomorphidae. Ruthenica (Suppl. 2), 1035-1166.

Silva, A. L. (2007). Habroconus (Pseudoguppya) semenlini (Moricand, 1845) (Gastropoda, Stylommatophora, 
Euconulidae) e malacofauna acompanhante de um fragmento de floresta nativa alterada, no Campus do Vale da Universidade Federal do Rio Grande do Sul, Porto Alegre, Brasil (Dissertação de Mestrado). Instituto de Biociências, Universidade Federal do Rio Grande do Sul, Porto Alegre, Bazil. Retrieved from http:// www.lume.ufrgs.br/handle/10183/14958

Silva, L., Meireles, L., Vargas, T., Junqueira, F. O., \& Bessa, E. C. A. (2009). Life history of the land snail Habroconus semenlini (Stylommatophora: Euconulidae) under laboratory conditions. Revista de Biología Tropical, 57(4), 1217-1222. Retrieved from http://www.scielo.sa.cr/scielo.php?pid=S003477442009000400024\&script=sci_arttext

Suárez-Torres, A., \& Fernández-Velázquez, A. (2012). Subnicho estructural y densidad poblacional de Cerion politum maisianum y Polymita brocheri en Paso de los Azules, Maisí, Cuba. Novitates Caribaea (5), 66-72. Retrieved from https://doi.org/10.33800/ nc.v0i5.125

Suárez Torres, A., Hernández, I., \& Fernández, A. (2012). Abundancia, sustrato y estrato de Cerion peracutum peracutum (Mollusca: Pulmonata) en Guanabo, La Habana, Cuba. Solenodon, 10, 32-37. Retrieved from http://www.caribbeanahigroup.org/pdf/solenodon10/4_Cerion\%20peracutum.pdf

Schilthuizen, M. (2011). Community ecology of tropical forest snails: 30 years after Solem. Contributions to Zoology, 80(1), 1-15. Retrieved from http://dpc.uba. uva.nl/cgi/t/text/get-pdf?idno $=$ m8001a01; $=$ ctz

Thompson, F. G. (2011). An annotated checklist and bibliography of the Land and freshwater snails of Mexico and Central America. Ed. II. Bulletin of the Florida Museum of Natural History, 50, 1-299. Retrieved from http://www.flmnh.ufl.edu/malacology/ mexico-central america snail checklist

Villalobos, M. C., Monge-Nájera, J., Barrientos, Z., \& Franco. J. (1995). Life cycle and field abundance of the snail Succinea costaricana (Stylommatophora: Succineidae), a tropical agricultural pest. Revista Biología Tropical, 43(1-3), 181-188. Retrieved from https:// revistas.ucr.ac.cr/index.php/rbt/article/view/22427

Winter, A. J., \& Gittenberger, E. (1998). The land snail fauna of a square kilometer patch of rainforest in southwestern Cameroon, high species richness, low abundance and seasonal fluctuations. Malacologia, 40, 231-250. Retrieved from https://www.biodiversitylibrary.org/page/13112180\#page/247/mode/1up 